African Crop Science Journal by African Crop Science Society is licensed under a Creative Commons Attribution 3.0 Uganda License. Based on a work at www.ajol.info/ and www.bioline.org.br/cs DOI: https://dx.doi.org/10.4314/acsj.v26i4.10

\title{
MORPHOTYPES, DISTRIBUTION AND USES OF FALSE BANANA IN UGANDA
}

\author{
M. ACERO, S.B. MUKASA ${ }^{1}$ and Y. BAGUMA ${ }^{2}$ \\ Faculty of Agriculture, Uganda Martyrs University, P. O. Box 5498 Kampala, Uganda \\ ${ }^{1}$ School of Agricultural Sciences, Makerere University, P. O. Box 7062 Kampala, Uganda \\ ${ }^{2}$ National Crops Resources Research Institute, NARO, P. O. Box 7084 Kampala, Uganda
}

Corresponding author: miriaacero@gmail.com

(Recieved 15 January, 2016.; accepted 20 November, 2018)

\begin{abstract}
Enset (Ensete ventricosum) is commonly known as the "false banana" because of its close resemblance to the domesticated banana (Musa spp.) plant. It is Ethiopia's most important traditional staple crop in the densely populated south and south-western parts of the country; where it is grown and exploited for its starch to make various food and industrial products. In Uganda, little is known about enset regarding its ethno-botany and distribution, yet it occurs in the country. The objective of this study was to map out the distribution and document the ethno-botany and uses of enset in Uganda. A survey was carried out throughout the country to identify its natural habitats in different regions. Local people were interviewed on the uses of enset, etymology, and identification of different morphotypes. Morphological descriptors and sex of enset accessions were used in classification or identification of morphotypes. Enset was generally widely, but sparsely distributed in the different regions in Uganda; growing at elevations ranging between 988 (Moyo district) to 2,150 (Kapchorwa district) metres above sea level (masl) and in a variety of habitats. Out of the 80 districts of Uganda (as of 2009), enset was reported and observed in 30 districts. Thirteen local names of enset and their meanings were documented; but it was widely referred to as Kitembe. Different plant parts were used for medicinal purposes; while the leaves were used in local beer brewing. There were five enset morphotypes distinguished by morphological traits, such as plant height (short $v s$ tall), mid-rib colour (light green $v s$ pink), pseudostem background appearance (light green $v s$ brown), leaf margin colour, male bud colour, and leaf length-breadth ratio. A detailed molecular level genetic diversity assessment is recommended for further validation of the morphotypes.
\end{abstract}

Key Words: Ensete ventricosum, ethno-botany, etymology, morphotypes

\section{RÉSUMÉ}

Le Bananier d'Abyssinie (Ensete ventricosum) est communément appelé comme « fausse banane » à cause de sa très grande ressemblance au plant de banane (Musa spp) domestiqué. C'est un aliment de base traditionnel très important dans les régions de grande densité de population du Sud et Sud-Ouest d'Ethiopie ; où il est cultivé et exploité pour son amidon utilisé pour divers produits alimentaires et industriels. En Ouganda, très peu d'informations relatives à son ethnobotanique et à sa distribution sont disponibles sur Bananier d'Abyssinie, pourtant il est présent dans le pays. L'objective de cette étude était de cartographier la distribution et de documenter l'ethnobotanique et les usages du bananier d'Abyssinie en Ouganda. Une enquête a été conduite à travers le pays pour identifier ses habitats naturels dans différentes régions. Les populations locales ont été interviewées sur les usages du bananier d'Abyssinie, l'étymologie, et l'identification des différents morphotypes. Les descripteurs morphologiques et le sexe des accessions du bananier d'Abyssinie ont été utilisés dans la classification ou l'identification des morphotypes. Le bananier d'Abyssinie a été largement, but sporadiquement distribué dans 
les différentes régions en Ouganda ; les altitudes de cultures varient entre 988 (district de Moyo) à 2150 mètres (district de Kapchorwa) au-dessus du niveau de la mer (masl) et dans une variété d'habitats. Sur les 80 districts (comme en 2009), le bananier d'Abyssinie a été rapporté et observé dans 30 districts. Les treize noms locaux du bananier d'Abyssinie et leurs significations ont été documentés ; mais il a été largement référé au Kitembe. Les différentes parties du plant ont été utilisées à des fins médicinales, alors que les feuilles ont été utilisées dans la préparation de la bière locale. Il y avait cinq morphotypes du bananier d'Abyssinie distingués par des traits morphologiques, tels que la hauteur du plant (courte $v s$ haute), couleur de mid-nervure (vert-clair vs rose), fond d'apparence de pseudo tige (vert-clair vs marron), couleur de la marge de la feuille, mâle mais la couleur, et un ratio longueur/largeur de la feuille. Une évaluation détaillée de la diversité génétique moléculaire est recommandée pour davantage validation des morphotypes.

Mots Clés: Ensete ventricosum, ethnobotanique, étymologie, morphotypes

\section{INTRODUCTION}

Enset (Ensete ventricosum) belongs to the order Zingiberales, family Musaceae and genus Ensete (Baker and Simmonds, 1953; Simmonds, 1958). The genus Ensete comprises of about 7 species; 3 in tropical Africa, 1 in Madagascar and 3 in tropical Asia (Baker and Simmonds, 1953). Enset is commonly known as the "false banana" because of its close resemblance to the domesticated banana (Musa spp) plant. Like banana, enset is a large non-woody monocarpic evergreen perennial plant. It is a diploid species $(2 n=18)$ that phenotypically resembles a banana plant, but the edible parts are formed by the pseudostem and underground corm, rather than the fruit (Almaz et al., 2002). Enset ventricosum is the most important species in the genus in Ethiopia. It reaches 5-7 m tall and exists throughout much of the African continent (Cheesman, 1947; Simmonds, 1960). Although generally adapted to swampy and moist areas in central and eastern Africa, it is cultivated in Ethiopia for food and fiber (Randy et al., 2007).

In Ethiopia, E. ventricosum is referred to as enset and occurs naturally at 1,000-2,400 masl (Tsegaye and Westphal, 2002). For thousands of years, it has been used as food crop in Ethiopia, where it is domesticated (Smeds, 1995). Enset is primarily grown to produce a starchy food from the pseudostem, corm and stalk of the inflorescence. The mixture of the scraped pseudostem and pulverised corm and stalk of the inflorescence are fermented in a pit and the resulting product is called 'Kocho' in Ethiopia. 'Bulla' is prepared from the starchy liquid obtained by squeezing the mixture (Pijls et al., 1995). The leaf sheaths of enset provide good quality fibre for making ropes, baskets, suitcases, mats and sacks. The aerial plant parts are used as livestock feed. Ethiopians believe that particular enset landraces have various medicinal properties (Tsegaye and Westphal, 2002).

In Uganda, bananas of the East African Highland type are a predominant crop, especially in central, western and eastern Uganda parts of the country (Rubaihayo et al., 1994). The same areas are also good habitats for enset, where it has been reported to grow naturally, and is used as an ornamental crop (Acero et al., 2013). Little is known about enset distribution or its uses in East Africa. The aim of this study was to document the distribution and uses of enset in Uganda.

\section{METHODOLOGY}

A survey was carried out in 2009 in regions of central, eastern, northern, west-Nile, western and south-western Uganda (Table 1) to establish the geographical location and natural habitats for enset. Geographical Position System (GPS) readings were made at particular spots where enset plants occurred. In cases where enset plants grew in clusters, one plant was selected and taken for closer examination to represent a particular cluster. The collected enset plants were taken for $e x$ situ germplasm conservation at the National 
TABLE 1. Districts surveyed in different regions of Uganda for enset incidence.

\begin{tabular}{ll}
\hline Region & Districts \\
\hline Central & Wakiso, Mpigi, Mukono, Luwero, Rakai and Masaka. \\
Eastern & Jinja, Kamuli, Mayuge, Mbale, Bududa and Kapchorwa. \\
Northern & Amuru, Gulu, Lira, Apac and Oyam. \\
West-Nile & Nebbi, Paidha, Arua, Yumbe and Moyo \\
Western and southwestern & Hoima, Masindi, Kibale, Kiboga, Kabarole, Kasese, Bushenyi, and Kabale \\
\hline
\end{tabular}

Crops Resources Research Institute (NaCRRI), Namulonge.

At each location where enset plants were obtained, key information through a face to face interview following a questionnaire with the local people was obtained regarding the local names and their meanings, uses, ecology, morphological traits such as pseudostem girth, plant height, number and colour of seeds, and classification of enset according to the local people's understanding. In total, 132 respondents were interviewed where on average 5-6 people responded in each of the 30 districts. The respondents were selected by virtue of having enset growing either within their gardens or the people who were living close to habitats such as; forests, game reserves, waterfalls and wetlands where enset was found to exist.

GPS data points were entered into Arc-view 3.2a, which dispersed them according to their respective geographical locations. These dispersed points were transposed onto the particular districts where enset occurred. Data on the ethno-botany of enset were analysed using Statistical Package for Social Scientists and a catalogue of its local names was made.

\section{RESULTS AND DISCUSSION}

Distribution and elevations for enset growing. Enset was widely distributed throughout the six regions of Uganda (Fig. 1). Out of the 80 districts of Uganda (as of 2009), enset was reported and observed in 30 districts of the country. Enset plants were found in the central Uganda districts of Kiboga, Luwero, Masaka Mpigi, Mukono, Rakai and Wakiso; in the eastern region districts of Bududa, Mbale and Kapchorwa; in the western region districts of Hoima, Kibaale, and Masindi; and in the south-western region districts of Bushenyi, Kabale and Kasese. In the northern region, the plants were found in Gulu, Lira, and Apac while in west-Nile, they were in Nebbi, Arua, Yumbe and Moyo (Fig. 1). Enset plants were found growing at elevations ranging between 988 (Moyo district) - 2,150 (Kapchorwa) masl (Table 2)

In Ethiopia, enset occurs naturally between 1,000 - 2,400 masl (Tsegaye and Westphal, 2002). Under cultivation, it occurs at altitudes of 1,600-3,100 masl, but scattered plants can be found at lower altitudes (Tsegaye and

TABLE 2. Elevations ranges at which Enset plants were found growing in different regions and districts of Uganda

\begin{tabular}{llc}
\hline Region & District & Elevations (masl) \\
\hline Central region & Mukono & 1,147 \\
& Masaka & 1,278 \\
Eastern & Bududa & 1,520 \\
& Kapchorwa & 2,150 \\
Western & Masindi & 1,090 \\
& Kibaale & 1,273 \\
South-western & Bushenyi & 1,413 \\
& Kabale & 1,946 \\
Northern & Gulu & 1,021 \\
& Lira & 1,110 \\
West-Nile & Moyo & 988 \\
& Arua & 1,606 \\
\hline
\end{tabular}




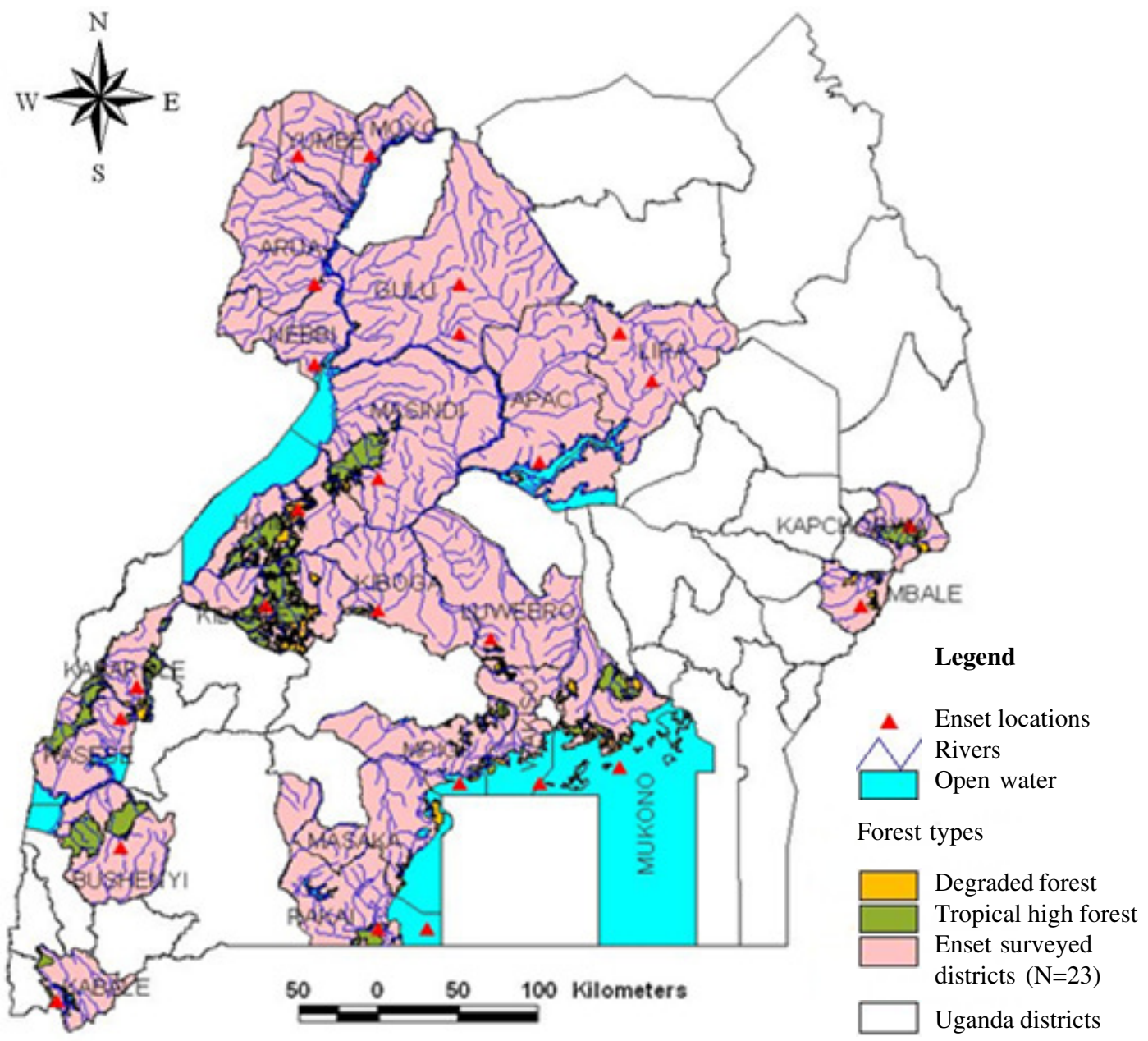

Figure 1. The distribution and incidence of Ensete species in their natural habitats in Uganda. Out of the 80 districts of Uganda (as of 2009), enset was reported and observed in 30 districts of the country.

Westphal, 2002). The species E. gilletii, grows at elevations ranging between $900-1,100$ masl; E. glaucum can grow up to 1,100 masl; while $\mathrm{t} E$. ventricosum can grow at elevations between 1,800-2,150 masl. Ensete superbum and E. wilsonii can even grow up to 2,700 masl (Cheesman, 1947).

The elevation range (988 - 2,150 masl) at which enset plants were collected in Uganda suggests that the climatic conditions in this country are favourable for the growth of the different Ensete species. Moreover, the highest elevation at which enset was found growing in Uganda (2,150 masl) is far less than 2,450 masl an elevation above which the growth of enset can be hindered due to frost (Tsegaye and Westphal, 2002). From the morphological descriptors, the dominant Ensete species in Uganda is E. ventricosum.

Habitats for enset growing. In central Uganda, enset plants were mainly concentrated in forests, islands and by the lakeshores (Fig. 2). In a few cases, enset was recorded in grasslands and in rocky areas of northern Uganda and west-Nile. In eastern Uganda, they were found in mountainous areas within gamereserves, near waterfalls, gardens and in 


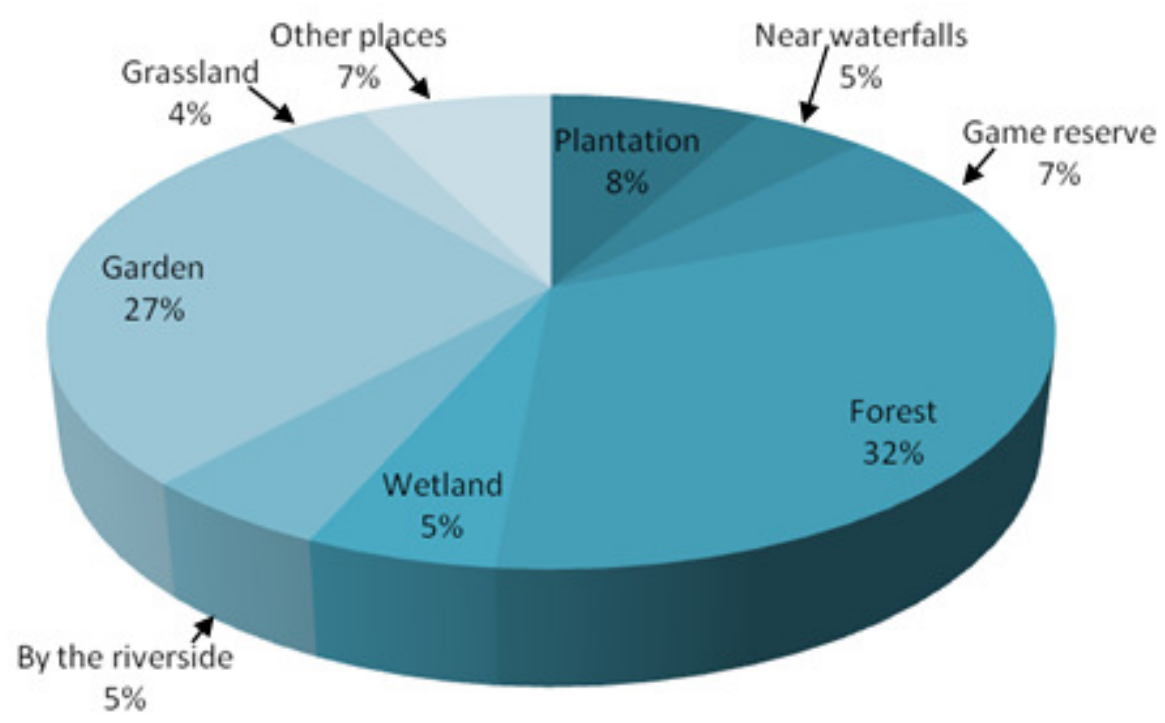

Figure 2. The habitats of enset plants in the different regions in Uganda, N=132 (interviewees).

compounds. In western and south-western Uganda, the plants were found in wetlands, tea plantations and by riversides. Similar habitats were reported to be favourable for enset (Tsegaye and Westphal, 2002). Natural forests were reported to harbour wild relatives of the domesticated enset (Almaz et al., 2002). Tsegaye and Westphal (2002) reported the natural occurrence of enset in montane and rivarine forests. Other species of Ensete have been reported elsewhere in Africa, and probably different agroecologies. Ensete gilletii is found in Angola, Guinea-Conakry, Mali, SierraLeone, Ivory Coast, Ghana, Togo, Benin, Nigeria, Democratic Republic of Congo and Malawi (Baker and Simmonds, 1953).

According to the local people interviewed in various districts of Uganda, the growth of Ensete ventricosum is favoured by a wide range of ecological conditions (Fig. 3). Most people $(89 \%)$ said that it grows in waterlogged conditions; while others $(53 \%)$ claimed that it requires dark fertile loam soils for vigorous growth. Some respondents reported that enset grows in clay soils $(30 \%)$; while others $(21 \%)$ in forests. These observations are in agreement with previous reports from Ethiopia that enset grows well in fertile that are ideally moderately acidic ( $\mathrm{pH} 5.6$ - 7.0) with 2-3\% organic matter (Tsegaye and Westphal, 2002). Other conditions which favour the growth of enset are in mountainous areas (8\%) (Fig. 3). Knowledge of the ecological conditions which favour the growth of enset is very important for in-situ and ex-situ conservation of the plant. Moreover, farmers and breeders who need to cultivate this wild species can understand how to manipulate the environmental conditions to favour the domestication of enset.

Etymology and names of enset. Given the numerous socio-cultural settings and ethnic groups in Uganda, enset was found to have a variety of local names (Table 3). Moreover, the commonest synonym in the local names of enset was 'tembe' which gave rise to names such as Ekitembe among the Baganda (central Uganda) and Basoga (eastern Uganda), Ekiteembe among the Banyoro (western Uganda) and Batoro (south-western Uganda), Omutembe among the Bakiga (south-western Uganda) and Latembe among the Acholi (northern Uganda) (Table 3). Among the Lugbara, it is called Ole-abua, which literally 


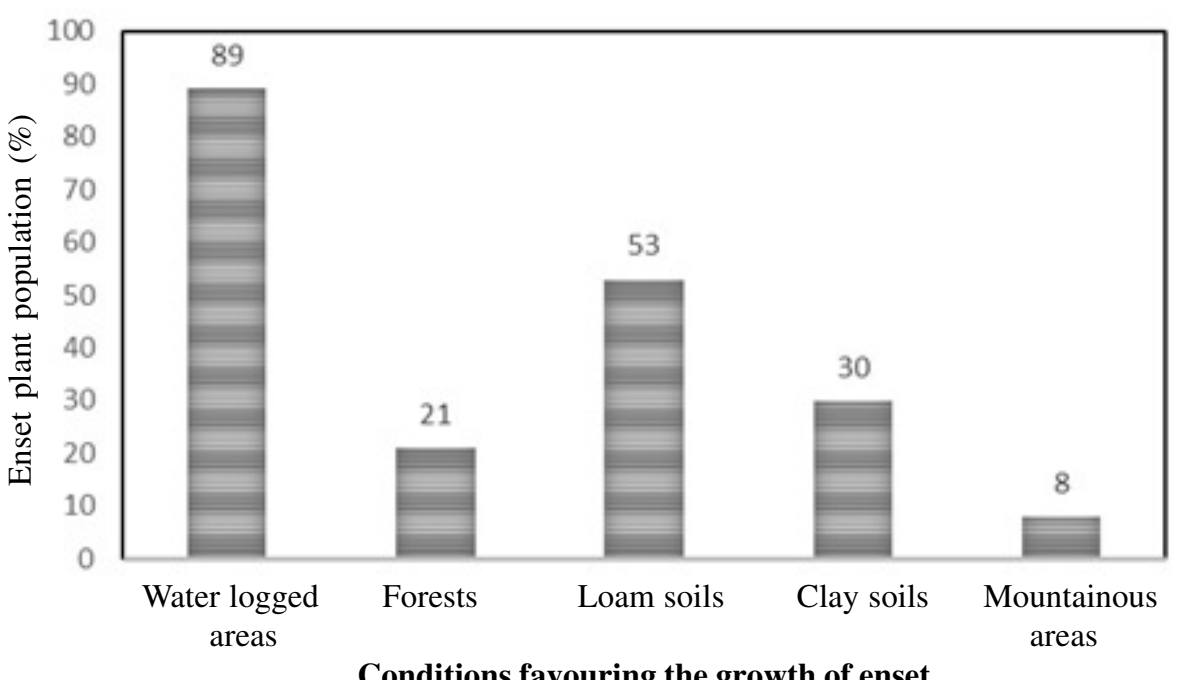

Figure 3. Conditions favouring the growth of enset according to the local people interviewed $(\mathrm{N}=132)$ from the different regions in Uganda.

TABLE 3. Catalogue of local names of enset in different languages and regions of Uganda

\begin{tabular}{lll}
\hline Region & Local name & Local language \\
\hline Central & Ekitembe & Luganda \\
& Ekitembe & Lusoga \\
Eastern & Sigomu & Lugisu \\
& Sasuruwet & Kup'sabiny \\
& Ekiganwa & Runyarwanda \\
Western and southwestern & Ekitaheta & Rukonjo \\
& Ekiteembe & Rutoro \\
& Ekiteembe & Runyoro \\
& Ekizirankoma & Runyankole \\
& Omutembe & Rukiga \\
& & \\
& Latembe & Acholi \\
Northern & Otodi & Langi \\
& & \\
West-Nile & Minbiku & Alur \\
& Ole-abua & Lugbara \\
& Oya-bugu & Madi \\
\hline
\end{tabular}


means 'wizard's banana'; while among the Madi, it is called Oya-bugu which means 'monkey's banana'.

In the Bantu languages (Baganda, Basoga, Banyoro, Batoro, Bakiga) the syllable "tembe or the verb okutembula" signifies early settlement probably suggesting the occurrence of this species in the great lakes region before the East African Highland bananas. One of the East African Highland bananas, whose name relates to "tembe" is Nakitembe, which is held in the Baganda culture as the first banana cultivar to be domesticated in the region. Other variants of the name Nakitembe include Nakitembut (Kapchorwa district).

In Ethiopia, vernacular names for enset include enset (Amhara), asat (Gurage), weise (Kambata) and wassa (Sidama) (Tsegaye and Westphal, 2002). In most villages in Ethiopia, the common names of enset are shared among the people (Yemane and Kebeber, 2006). Farmers give separate vernacular names for each landrace. The names are often descriptive and reflective of variations of landraces in places of origin, morphology, agronomic and cooking characteristics (Temesgen et al., 2014).

Although folk botanical nomenclature is not guided by a set of written rules, there are striking similarities in the way plants are named by local people around the world (Martin, 1995; Yemane and Kebeber, 2006). To facilitate the understanding of the challenge of variability and diversity of Ensete spp. and clearly develop scientifically acceptable biological classification, Awegechew (1996) argues that both folk botanical and scientific taxonomy should be taken into consideration.

Classification of enset. According to the local people in Uganda, enset has numerous morphological traits (Fig. 4). Most people (37\%) observed that enset has larger leaves compared to Musa spp. while others (30\%) indicated that it has a larger pseudostem compared to Musa spp. About $16 \%$ of the respondents indicated that enset produces seeds instead of an edible fruit (Fig. 4). Other morphological traits exhibited by enset include erect leaves, big male bud, a long bunch, short fruit fingers and inability to produce suckers as known for banana (Fig. 4).

The enset morphotypes in the different regions of the country were differentiated based on morphological characteristics such as mid-rib colour, leaf margin colour, pseudostem background appearance, leaf length/width ratio, pseudostem length/girth ratio and corm width. These morphological traits were the basis for the variations across the different morphotypes. Ensete ventricosusm had different classifications according to the local people in Uganda. Some people (29\%) classified enset according to

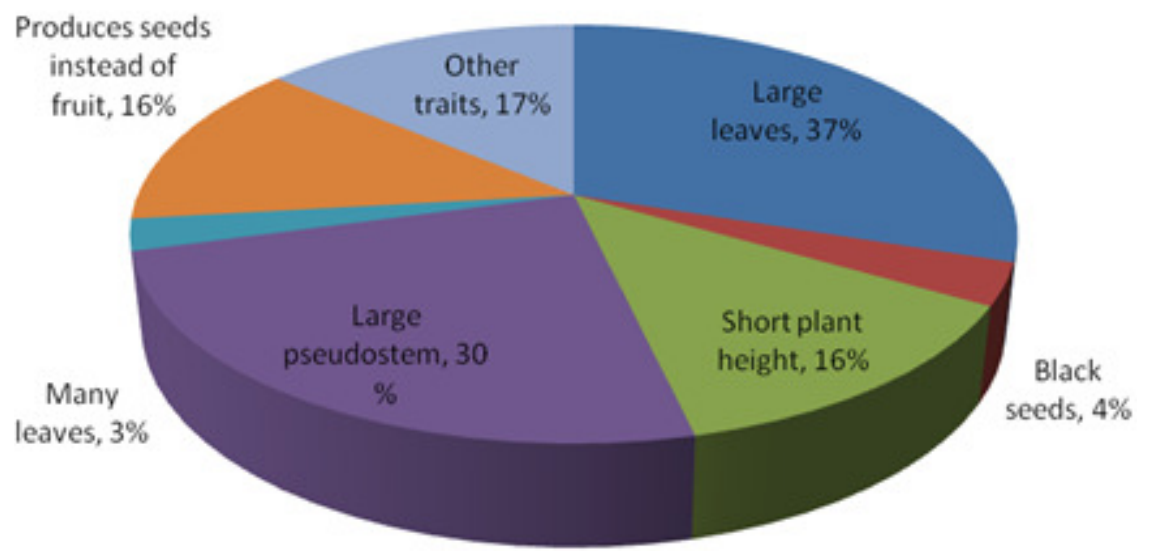

Figure 4. Morphological traits of Ensete ventricosum according to the local people, N=132 in Uganda. 
'sex', claiming that there is a 'male' and 'female' group; while other classifications were based on colour of the midribs (18\%), plant height $(17 \%)$, shape of the pseudostem (12\%), breadth and leaf length (12\%), colour of the pseudostem $(6 \%)$ and fruiting ability $(6 \%)$.

Thus, enset plants in Uganda are separable from one another by characters generally inherent in vegetative structures such as leaf orientation, shape, colour, width, length, strength and variegation into morphotypes. In this study we observed five enset morphotypes (Table 4), distinguished by morphological traits such as mid-rib colour, pseudostem background appearance, leaf margin colour and male bud colour. It was interesting to note how $4 \%$ of the local people in Uganda could associate gender with the enset accessions, a thing that was not conceived prior to this study.

Zippel and Kefale (1995) reported that enset phenotype can be distinguished by plant height, shape and colour of inflorescence. Although the numeric taxonomy of enset is not well established, farmers in Ethiopia are capable of differentiating several varieties based on morphological and end-use qualities (Yemane and Kebeber, 2006). The pseudostem length as well as girth, colour, orientation and lifting of leaf sheaths), and the corm size, colour and hardness have also been used in morphological taxonomy of enset in Ethiopia (Tesfaye, 2008). Furthermore, agronomic characteristics including reaction to drought, diseases and pests, and maturity time can also be used for enset identification

In Ethiopia, all Ensete ventricosum plants are classified as either 'male' or 'female' (Bizuayehu, 2008). These are symbolic, metaphorical gender terms, as enset plants are hermaphroditic. The 'male' or 'female' attribution has to do with size differences and with food qualities. 'Female' varieties are smaller than 'male' enset types. The 'female' ensets have sweet, softer pulps than those of the 'male' types. The 'male' types have larger, tougher corms which are fibrous and bitter and unattractive to pests. The 'female' enset plants are more prone to predation and are 'weaker', more sensitive to drought, wind and frost (Bizuayehu, 2008). The 'female' groups are recognised by ease of scrapping, early fermentation and low yield while the 'male' groups contrast to these traits (Melesse $e$ al., 2014). However, differentiation of the five morphotypes discerned in this study could further be validated with molecular

TABLE 4. Number of plants belonging to different sub-populations (morphotypes) of Ensete spp. sampled in the different regions in Uganda $(\mathrm{N}=132)$

\begin{tabular}{lrrrrrr}
\hline Region & SBPI & SBPII & SBPIII & SBPIV & SBPV & Total \\
\hline Central & 11 & 2 & 20 & 6 & 0 & 39 \\
Eastern & 3 & 1 & 2 & 28 & 0 & 34 \\
Northern & 0 & 0 & 1 & 8 & 0 & 09 \\
West-Nile & 0 & 0 & 0 & 12 & 0 & 12 \\
Western & 0 & 0 & 2 & 0 & 3 & 05 \\
South-Western & 8 & 0 & 23 & 0 & 2 & 33 \\
Total & 22 & 3 & 48 & 54 & 5 & 132 \\
\hline
\end{tabular}

Note: SBP = Sub-population; SBPI = Pink mid-ribs on underside only, brown pseudo stem, blackish-brown leaf margins and purple male bud; SBPII = Pink mid-ribs on underside only, green pseudo stem, blackish-brown leaf margins and purple male bud; SBPIII = Pink mid-ribs on underside only, purple pseudo stem, blackish-brown leaf margins and purple male bud; SBPIV = Pink mid-ribs on both sides, brown pseudo stem, blackish-pink leaf margins and purple male bud; SBPV = Green mid-ribs on both sides, green pseudo stem, blackish-brown leaf margins and green male bud 
characterisation that could allow detailed genetic diversity assessment of enset in Uganda.

Ethnobotany of enset. In Uganda, enset was found to have numerous uses among the local people from the different regions (Fig. 5). The leaves were used for brewing, thatching, as umbrellas and for wrapping feedstuff. Its seeds are used for playing a board game, for casting lots by witch doctors, for mathematical purposes, for decorating handicrafts and for making waist beads. The plant is also used for ornamental purposes and for shade in homesteads (Fig. 5). The different plant parts of enset are commonly used for medicinal purposes $(64 \%)$. Among the ailments which the plant reportedly cures are fever, headache and measles and local people claim that 'juice' squeezed from enset pseudostem is given to lactating animals; and women to increase milk production. Its leaves are used for brewing a local alcoholic drink $(35 \%)$

According to respondents, enset leaves are commonly used for brewing a local alcoholic drink, especially in eastern Uganda. In Ethiopia, where most uses of enset have been reported, enset corm is used to make three different food products known as, 'Kocho', 'Bulla' and
'Amicho' which are eaten especially in the south-western parts of Ethiopia. Particular land races and parts of enset have medicinal value for both humans and animals (CDI's Enset Manual, 2000). Traditional enset medicines include; 'porridges' for strengthening women after delivery and healing bone fractures in humans, a highly fermented product for curing stomach cramps, boiled corm for birth control and abortions in humans which is also fed to cows to facilitate placental expulsion (Temesgen et al., 2014). Enset fibre is a byproduct with an excellent structure used for weaving African crafts (Brandt et al., 1997). These African crafts include shopping bags, handbags, suitcases and mats. All parts of enset are good sources of animal feed.

Most of the uses found in Ethiopia are not well embraced by farmers in Uganda. Except for ornamental purposes, enset of kitembe is not regarded as a cultivated plant. The people who use it source it from its natural habitats. These habitats are rapidly disappearing due to deforestation and land degradation (Agea et al., 2007). These natural habitats are being encroached for agriculture and livestock keeping. Low levels of exploiting enset, a bioresource, especially as food or medicinal use, could be partly be due to availability of more alternatives as opposed to situations in

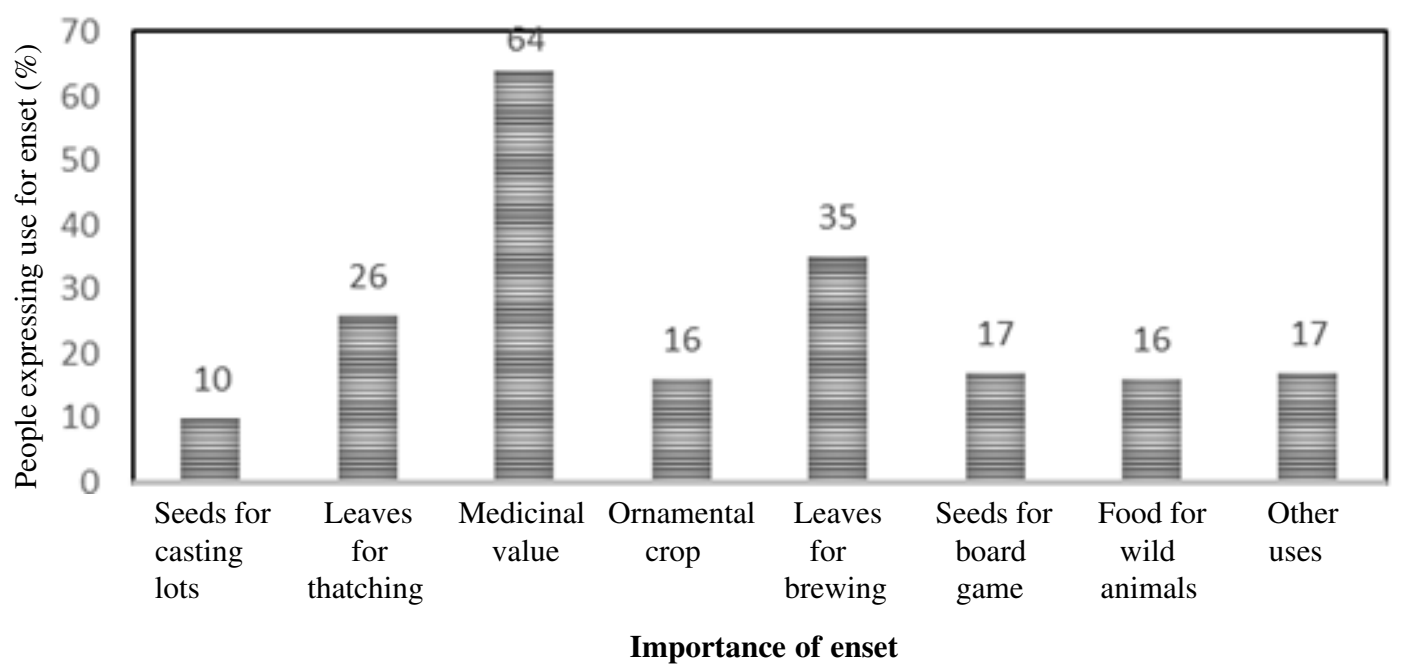

Figure 5. Importance of enset among the local people in the different regions in Uganda, N=132. 
Ethiopia; or farmers in Uganda have not been exposed to the vast possible uses of enset.

\section{CONCLUSION}

The false banana (enset or kitembe) is generally widely but sparsely distributed in the different regions in Uganda. The plant is known by different, though in some cases related, names in the various local languages in Uganda. The local people have considerable, but dissimilar knowledge on uses including medicinal applications and ecology of enset. The data on morphological traits provided by the local people is useful in the classification of the different enset morphotypes. However, differentiation of the five morphotypes could further be validated with molecular characterisation that could allow detailed genetic diversity assessment of enset in Uganda. This information is vital for $e x$-situ conservation and exploitation of enset for different industrial applications such as the food, pulp, textile and pharmacology.

\section{ACKNOWLEDGEMENT}

This study was funded by Swedish International Development Cooperation Agency/SAREC (Sida/SAREC), through the East African Regional Research Network for Biotechnology, Biosaftey and Biotechnology Policy Development (BIOEARN/02). The contribution of the Cassava Programme of the National Crops Resources Research Institute (Namulonge, NARO) and Makerere University is highly appreciated.

\section{REFERENCES}

Acero, M., Mukasa, S. and Baguma, Y. 2013. The False Banana (Ensete species) in Uganda. ISBN-13: 978-3659474200. Lambert Academic Publishing. Berlin, Germany. 88 pp.

Agea, J.G, Namirembe, S., Bukenya, M., Zziwa, A. and Waiswa, P. 2007. Design of
Appropriate Agroforestry Interventions in Uganda. Fountain Publishers, Kampala Uganda. Paperback, ISBN 978-9970-02677-7.

Almaz, N., Admasu T., Rob van Treuren and Bert, V. 2002. AFLP Analysis of Enset Clonal Diversity in South and South Western Ethiopia for Conservation. Crop Science 42:1105-1111.

Awegechew, T. 1996. Sorghum (Sorghum bicolor (L.) Moench) landrace variation and classification in North Shewa and South Welw, Ethiopia. Euphytica 97: 255-263.

Baker, R.E.D. and Simmonds, N.W. 1953. The genus Ensete in Africa. Kew Bulletin 8:405416, with a correction in Kew Bulletin 8:574.

Bizuayehu, T. 2008. On sidama folk identification, naming and classification of cultivated enset (Ensete ventricosum) varieties. Genetic Resources and Crop Evolution 55:1359-1370.

Brandt, A.S., Anita, S., Hiebsch, C., Mc Cabe, J.T., Endale, T., Mulugeta, D., Gizachew, W.M., Gebre, Y. Masayoshi, S. and Shiferaw, T. 1997. The Tree Against Hunger - Enset based agricultural systems in Ethiopia. American Association for the Advancement of Science, Washington, D.C., USA. 56 pp.

CDI's Enset Manual. 2000. Available at: http:/ /www.cdi-ethiopia.org/images/CD\%20 Enset-manual.pdf

Cheesman, E.E. 1947. Classification of bananas II. The genus Musa L. Kew Bulletin 2:106-117.

Martin, J.G. 1995. Ethnobotany. A methods manual. Chapman and Hall, London.

Melesse, M., Sileshi, N. and Tamray, B. 2014. Diversity and Distribution of Enset (Ensete ventricosum (Welw.) Cheesman). Landraces in Kambatta Tembaro Zone, Southern Ethiopia. Proceedings of the $4^{\text {th }}$ National Conference on Environment and Development. Dilla, Ethiopia. pp. 104-120.

Pijls, L.T.J., Timmer, A.A.M., Wolde-Gebriel, Z. and West, C.E. 1995. Cultivation, 
preparation and consumption of Enset (Ensete ventricosum) in Ethiopia. Journal of the Science of Food and Agriculture 67:1-11.

Rubaihayo P.R., Makumbi D. and Mukasa S.B. 1994. Preliminary evaluation of banana and plantain cultivars for resistance to black sigatoka in central Uganda. African Crop Science Conference Proceedings 1: 237239.

Simmonds, N.W. 1958. Ensete cultivation in the Southern Highlands of Ethiopia: A Review. Tropical Agriculture 35:305-307.

Smeds, H. 1995. The Enset planting culture of Eastern Sidamo, Ethiopia. Acta Geographica 13:2-39.

Temesgen, M.O., Bizuayehu, T., Marcello, C. and Marcio, E.P. 2014. Indigeneous Knowledge, use and on-farm management of enset (Ensete ventricosum (Welw.) Cheesman) diversity in Wolaita, Southern Ethiopia. Journal of Ethnobiology and Ethnomedicine 10:41.
Tesfaye, B. 2008. The Enset (Ensete ventricosum) gardens of Sidama: Composition, Structure and dynamics of a traditional poly-variety system. Genetic Resources and Crop Evolution 55:13471358.

Tsegaye, A. and Westphal, E. 2002. Ensete ventricosum (Welw.) Cheesman. Records from Protabase. Plant Resources of Tropical Africa. University of Agriculture, School of Graduate Studies. Alemaya, Ethiopia. $81 \mathrm{pp}$.

Yemane, T. and Kebeber, F. 2006. Diversity and cultural use of Enset (Ensete ventricosum (Welw.) Cheesman) in Bonga insitu conservation, Ethiopia. A Journal of Plants, People and Applied Research. Ethnobotany Research and Applications 4:147-157.

Zippel, K. and Kefale, A. 1995. Field guides to enset landraces of North Omo, Ethiopia, Farmers' Research Project. Technical Pamphlet number 9, FARM Africa, Addis Ababa, Ethiopia. 